\title{
Upland erosion under a simulated most damaging storm
}

\author{
S. J. LINSE, D. E. MERGEN, J. L. SMITH, AND M. J. TRLICA
}

Authors are environmental engineer, Western Water Consultants, 611 Skyline Road, Laramie, Wyo. 82070; research associate, Rangeland Ecosystem Science Department, Colorado State University, 5212 Kissing Camel Drive, Colorado Springs, Colo. 80904; professor emeritus of Civil Engineering, University of Wyoming, Laramie, Wyo. 82071; and professor of Rangeland Ecosystem Science, Colorado State University, Ft. Collins, Colo. 80523.

\begin{abstract}
A 2 year study was conducted to determine the effects of surface cover and roughness on sediment yield from plots subjected to a simulated most damaging storm. This storm, based on long term sediment records from 3 Wyoming streams, produced approximately $18 \mathrm{~mm}$ of precipitation in $15 \mathrm{~min}$ with an intensity of $97 \mathrm{~mm}_{\text {hour }}{ }^{-1}$. The rainfall simulator covered 2 plots; each 0.6 by $2 \mathrm{~m}$. Plots were on $9 \%$ slopes with highly erosive soils (silt and fine sand texture) on native rangeland in 3 areas of Wyoming. Cover and surface roughness were measured with a point frame.

Sediment production typically peaked approximately $120 \mathrm{sec}$ after runoff started and reached steady state within 6 min. Plots with no cover (tilled) seldom produced runoff due to high infiltration and the short duration rainfall. Sediment yield was moderately correlated with total cover for total cover less than $30 \%$, and sediment yield decreased to 0.1 tonnes ha ${ }^{-1}$ (assumed allowable soil loss) or less for greater than $30 \%$ cover. There was a weak correlation between surface roughness and sediment yield, and surface roughness was slightly correlated with total cover. These results suggested that maintaining at least $30 \%$ total cover could control sediment yields from short duration-intense storms. Experimental results also indicated considerably higher sediment yields than those predicted by the Revised Universal Soil Loss Equation or a modified version of that equation.
\end{abstract}

Key Words: sediment yield, surface cover, surface roughness, eolian sediment, RUSLE, non-point source pollution, water quality

Sediment contaminates more kilometers of Wyoming's rivers and streams than any other non-point source (Hogan 1988), a situation typical in many western states (Heady and Child 1994). Runoff and sediment transported with runoff from rangelands also transports biological and chemical pollutants into rivers and streams while removing vital plant nutrients. Thus, erosion decreases range productivity (Binkley and Brown 1993), and pollutants accumulate in water supplies, which reduces water quality (Hogan 1988).

Vegetation cover, plant life form (grasses, forbs, shrubs), ground cover, soils, and topography influence runoff and erosion (Simanton et al. 1991, Benkobi et al. 1994). The type and amount

This research was funded by the State of Wyoming Department of Environmental Quality, Non-point Source Program.

At the time of this research, the first author was Graduate Assistant, Department of Civil Engineering, University of Wyoming.

Manuscript accepted 2 Sept. 2000.

\section{Resumen}

Se condujo un estudio de 2 años para determinar los efectos de la cobertura superficial y la rugosidad en la producción de sedimento de parcelas sujetas simulación de la tormenta mas dañina. Esta tormenta, basada en registros de largo plazo de la producción de sedimento de 3 corrientes de Wyoming produjo aproximadamente $18 \mathrm{~mm}$ de precipitación en 15 minutos con una intensidad de $97 \mathrm{~mm}$ hora $^{-1}$. El simulador de lluvia cubrió 2 parcelas, cada una de 0.6 × $2 \mathrm{~m}$. Las parcelas se localizaron en tres áreas de Wyoming en pastizales nativos con pendientes del 9\% y suelos altamente erosivos (textura de limo y arena fina). La cobertura y rugosidad de la superficie se midieron con un marco de puntos. La producción de sedimento típicamente estuvo en su mas alto punto a los 120 segundos después de que inicio el escurrimiento y alcanzo el estado de equilibrio dentro de 6 minutos. Las parcelas sin cobertura (con labranza) raramente produjeron escurrimiento debido a la alta infiltración y a la corta duración de la lluvia. La producción de sedimento se correlaciono moderadamente con la cobertura total en coberturas menores al $30 \%$ y la producción de sedimento disminuyo a 0.1 ton $\mathrm{ha}^{-1}$ (perdida de suelo que se asume permitida) o menos en coberturas mayores al $30 \%$. Hubo un a correlación débil entre la rugosidad de la superficie y la producción de sedimento y la rugosidad de la superficie se correlaciono ligeramente con la cobertura total. Estos resultados sugieren que manteniendo al menos $30 \%$ de cobertura total se podría controlar la producción de sedimiento de tormentas de corta duración-alta intensidad. Los resultados experimentales también indicaron producciones de sedimento considerablemente mas altas que las predichas por la Ecuación Universal de Perdida de Suelo Revisada o una versión modificada de esa ecuación.

of vegetation also affects the spatial and temporal variation of runoff and erosion (Weltz and Wood 1986, Blackburn and Wood 1990). Eolian sediment deposition, which is influenced by the same factors (Skidmore 1994), may be an important source of sediment from rangelands during precipitation events. Wind speeds of $40 \mathrm{~km} \mathrm{hour}^{-1}$ (less than twice the average daily wind speed on many rangelands) cause erosion at approximately the same rate as many precipitation events, but windstorms occur more frequently (Skidmore 1994).

Rangeland runoff and erosion are controlled by a complex combination of soil, plant, microtopographic, and hydrologic interactions (Seyfried 1991, Weltz and Blackburn 1995). For example, the spatial arrangement of vegetation and plant life form affects litter and roughness of the soil surface (Blackburn et al. 1992) thereby affecting runoff and sediment filtration (Weltz 
et al. 1992) and soil properties (Naeth et al. 1991). Coppice dunes, which may be partially formed by deposition of eolian sediment, are associated with surface roughness and aggregate stability, and by influencing infiltration, influence runoff and erosion (Blackburn et al. 1990). Eolian sediment typically has the same texture (silt and fine sand) as soils which are highly susceptible to rainfall erosion. While there is ample evidence in the literature of the impact of precipitation events on runoff and erosion, there is little information to show the impact of vegetation and soil surface characteristics on sediment yield caused by a "most damaging storm".

The objective of this research was to evaluate the effects of cover and surface roughness on the sediment yield caused by a simulated most damaging storm. Sediment yield was defined as the amount of soil detached from an area which passed a downslope point (Ponce 1989), and the most damaging storm was defined as the rainfall event which caused the greatest average annual sediment load for 3 Wyoming streams (Huffsmith 1988). It was hypothesized that sediment yields produced by a most damaging storm would be greater and more sensitive to cover than those predicted by the Revised Universal Soil Loss Equation (Renard et al. 1994) or a modified version of that equation (Benkobi et al. 1994).

\section{Methods}

\section{Study Site}

Three upland range sites were selected for this research; Fifteen Mile drainage west of Worland, Wyo. (108 $20^{\prime} \mathrm{W}$, $\left.44^{\circ} 11^{\prime} \mathrm{N}\right)$, provided the least cover, Ten Mile Creek north of Worland, Wyo. $\left(108^{\circ} 8^{\prime} \mathrm{W}, 44^{\circ} 21^{\prime} \mathrm{N}\right)$, provided intermediate cover, and areas along Beaver and Jack Creeks south of Rawlins, Wyo. $\left(107^{\circ} 7^{\prime} \mathrm{W}\right.$, $\left.41^{\circ} 27^{\prime} \mathrm{N}\right)$, provided the greatest cover. Soil types were different at the 3 sites; however, surface soils at all sites had similar texture. Vegetative and cover differences were evaluated in terms of height, total cover, canopy cover, litter, rock, and biomass.

Fifteen Mile Drainage receives a mean annual precipitation of $203 \mathrm{~mm}$ and has an average annual temperature of $7^{\circ} \mathrm{C}$. Soils belong to the Greybull-Persayo association. The drainage is sparsely vegetated with saltbush (Atriplex spp.), pricklypear cactus (Opuntia spp.), blue grama (Bouteloua gracilis (H.B.K.) Lag.), and various shrubs. Steeply sloped badlands cover much of the area. Primary historical uses are grazing, recreation, and oil and gas production. The drainage contributes approximately $0.8 \%$ of the mean annual flow of the Bighorn River, but also contributes $75 \%$ of the annual sediment load (Cooper 1979).

Ten Mile Creek has the same average rainfall and temperature as Fifteen Mile, but has greater canopy cover. Soil in the area is an Uffens-Rairdent complex. Vegetation consists of wheatgrasses (Agropyron spp.), needle-and-thread (Stipia comata Trin.\&Rupr.), and big sagebrush (Artemisia tridenta Nutt.) with limited blue grama and pricklypear cactus. Primary historical use is for grazing, but there was no evidence of grazing before the simulations were run.

Beaver and Jack Creeks are in the Stratton Sagebrush Hydrology Study Area. Soils belong to the Youga series, mixed Argic Cryboroll. Beaver Creek receives an annual precipitation of $381 \mathrm{~mm}$, has an annual average temperature of $5^{\circ} \mathrm{C}$, and was being grazed at the time of the simulations. Jack Creek receives an average annual precipitation of $516 \mathrm{~mm}$, has an average annual temperature of $5^{\circ} \mathrm{C}$, and has not been grazed since 1960 . Vegetation consists of big sagebrush and grasses such as fescues (Festuca spp.), blue grasses (Poa spp.), and needle grasses (Stipa spp.). Litter cover, which was often several $\mathrm{cm}$ thick, influenced cover and surface roughness at this site.

\section{Rainfall Simulator}

The rainfall simulator was a 0.2 scale model of the "Swanson type" simulator (Laflen et al. 1991) which covered 2 plots, each 0.6 by $2 \mathrm{~m}$. Pearce et al. (1998) found that sediment yields from plots of this size were more sensitive to cover and surface roughness than from larger (3 by $10 \mathrm{~m})$ Swanson plots. Simulator nozzles (Veejet 9570, Spraying Systems Inc. ${ }^{1}$ ), and operating parameters were selected based on laboratory calibration and nozzle manufacturer's data. Using these results, the nozzles were located on a radius of 1.6 $\mathrm{m}$ and height of $2.9 \mathrm{~m}$. This configuration, with an operating pressure of $42 \mathrm{kPa}$, produced a relatively uniform spray pattern over the plot areas. The median drop size ( $2 \mathrm{~mm})$ was within values discussed by Lal and Elliot (1994) for high intensity storms. Measured drop maximum velocity averaged $7.4 \mathrm{~m} \mathrm{sec}^{-1}$ compared to $6.5 \mathrm{~m}$ $\mathrm{sec}^{-1}$ for natural raindrops falling in still air (de Ploey and Gabriels 1980).

${ }^{1}$ Use of trade names is for information purposes only and does not constitute endorsement by the authors or their employers.
The most damaging storm was defined as the storm that produced the greatest average annual stream sediment load. Using records for $3 \mathrm{Wyoming}$ watersheds, Huffsmith (1988) showed that most damaging storms produced 16 to $19 \mathrm{~mm}$ of rainfall with return periods of approximately 2 years. Branson et al. (1981) concluded that many rangeland storms produced less than $17 \mathrm{~mm}$ of rainfall, had durations of less than $60 \mathrm{~min}$, and reached peak intensity in less than $10 \mathrm{~min}$. Using a relationship presented by Linsley et al. (1982), the minimum duration for such storms is approximately $7 \mathrm{~min}$. Assuming 15 min duration and using an analysis presented by Haan et al. (1994), the intensity should be approximately $100 \mathrm{~mm}^{\text {hour }}{ }^{-1}$. In preliminary tests, it was observed that plot runoff and sediment yield stabilized within 6 min or less with a simulator rainfall intensity of $97 \mathrm{~mm}$ hour $^{-1}$. Therefore, the simulator operating parameters represented a reasonable compromise of the most damaging storm.

\section{Cover and Surface Roughness}

Surface cover was the controlled variable in this research, and plots were selected at the 3 study sites over the range of 0 to $100 \%$ cover. Cover and surface roughness were measured using the point frame method (Bonham 1989). The point frame covered an entire plot and contained 100 equally spaced pins (20 rows and 5 columns). Pin height was measured relative to the frame top using a digital micrometer, and surface roughness was calculated as the standard deviation of the pin elevations (Renard et al. 1994). Cover type was calculated based on the cover (plant canopy, litter, rock, etc.) touched on the first hit of 50 pins.

\section{Field Experimental Procedure}

Specific plots were selected on $9 \%$ slopes and by visual observation of cover. A frame, which outlined both simulator plots and located the center of the simulator, was then placed on the ground parallel to the slope and sheet metal plot boundaries were driven approximately $3 \mathrm{~cm}$ into the soil. After collecting surface soil samples adjacent to the plots and surface roughness and cover data, covered collection pans were placed at the lower end of each plot, the plots were covered with plastic, and the simulator was started. The plastic was removed (time $=0$ ) and the times at which runoff started were recorded. Runoff samples were collected for 10 sec at times of 30,60, 90, 120,150, 180 $\mathrm{sec}$, and at each $60 \mathrm{sec}$ thereafter following the start of runoff. 
Eighteen simulations were run at Fifteen Mile with canopy cover ranging from 6 to $43 \%$ and surface roughness ranging from 1.5 to $15.7 \mathrm{~mm}$; 12 simulations were run at Ten Mile with canopy cover ranging from 5 to $62 \%$ and surface roughness ranging from 5.3 to $17.6 \mathrm{~mm}$; and 8 simulations were run at Beaver and Jack Creeks with canopy cover ranging from 29 to $73 \%$ and surface roughness ranging from 8 to $35 \mathrm{~mm}$. Simulations were also run on tilled plots (no cover) at Ten Mile and Beaver and Jack Creeks. Plots were not tilled at Fifteen Mile because of the presence of an erosion pavement. Tilled plots seldom produced runoff and were therefore excluded from the analysis. Seven plots identified as outliers were also excluded from the analysis (Belsley 1991).

\section{Laboratory Analyses}

The volume of runoff and mass of sediment collected in each sample (10 sec runoff) were determined by drying and weighing. Sieve and hydrometer analyses (ASTM D-442-63) were used to determine the texture of the surface soil on each simulation site. Although soil texture differed somewhat between the 3 sites, the soils had very little clay (maximum of $<7 \%$ finer than $0.002 \mathrm{~mm}$ ) and approximately $30 \%$ silt and fine sand $(0.002$ to $0.1 \mathrm{~mm})$. These soils are highly erosive (Goldman et al. 1986). The overall average soil texture was $4 \%$ clay, $17 \%$ silt and $79 \%$ sand.

\section{Results and Discussion}

\section{Sediment Yield}

Sediment mass in $10 \mathrm{sec}$ runoff samples was plotted as a function of time after runoff started. A typical simulation is shown in Figure 1. In all simulations, peak sediment mass was observed 120 to 180 sec after runoff started and sediment mass decreased to a relatively steady value within approximately $6 \mathrm{~min}$. For plots with total cover $<30 \%$, the steady value was generally less than $15 \%$ of the peak value. Highly erodible surface soil was flushed off the plot and then rainfall erosion occurred at a relatively constant rate. Schreiber and Renard (1978) and Wilcox and Wood (1988) reported similar initial flushing. Possible explanations for this response include disturbance caused by installing plot boundaries, desiccation of the soil surface during dry periods, surface sealing during the intense storm, and accumulated deposition of eolian sediment. Soil disturbance caused by installing plot boundaries was minimal because the plot

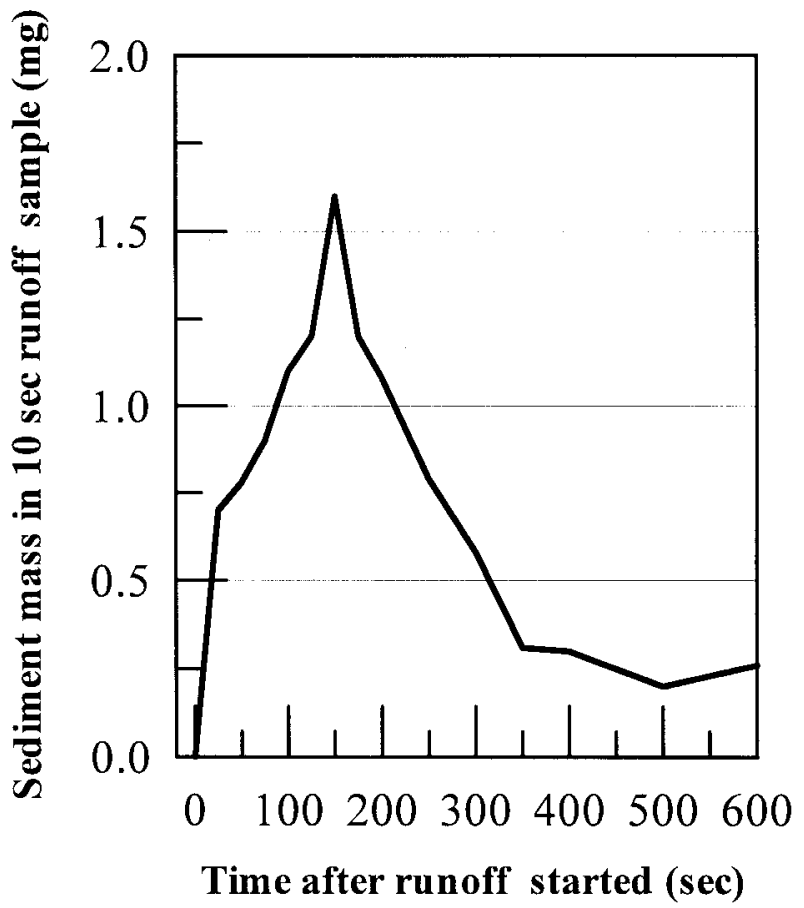

Fig. 1. Sediment mass in 10 sec runoff samples for a simulation with $26 \%$ total cover. The general shape of this curve is typical of most simulations, although the peak value decreased as total cover increased.

boundaries were driven rather than dug in. Surface soils were susceptible to desiccation and surface sealing because there was considerable fine sand and silt; however, tilled plots did not exhibit surface sealing.

Eolian sediment deposition would depend on wind characteristics, topographic features, and vegetation height, diversity, and morphological characteristics. In addition to accumulation on the ground surface, eolian sediment would be deposited on plant leaves and stems and would be washed off at the beginning of rainfall events. The accumulation of eolian sediment would also depend on the frequency of rainfall events of magnitude sufficient to transport sediment off the site. Devine et al. (1998) reported that spring time sediment yields observed in New Mexico might have resulted from wind deposition of fine sediment. Higher wind blown dust levels during winter and spring were also reported by Pease et al. (1998). The texture of eolian sediment, silt and fine sand (Skidmore 1994), is typical of the texture of the surface soils in this research.

Although this discussion is subjective, it offers an explanation for high stream sediment loads produced by short duration-high intensity storms which occur at approximately 2 year intervals. The time interval between these storms is sufficient for accumulation of eolian sediment in areas adjacent to streams under climatic conditions typical of many western rangelands.

\section{Cover}

With 7 data points deleted as outliers, regression analysis indicated that total cover explained $74 \%$ of the variability in sediment yield for total cover $\leq 30 \%$ (Fig. 2 ). However, regression analysis was not significant for total cover $>30 \%\left(\mathrm{r}^{2}=\right.$ 0.01) (Fig. 3). A possible explanation of these results is that micro-channel networks, which controlled sediment transport off the plots, were better developed on plots with total cover $\leq 30 \%$, and networks improved as total cover decreased from $30 \%$. However, for plots with total cover $>30 \%$, micro-channel networks were less developed and more random. Thus, sediment transport off plots with total cover $>30 \%$ was decreased and sediment yields were more random. Given the short duration of the simulated storm used in this study and the relatively small sediment yields, it is unlikely that micro-channel networks were altered significantly by the rainfall simulations.

On plots at Beaver and Jack Creeks with total cover $>70 \%$, litter cover explained $56 \%$ of the variability in sediment yield. Few if any raindrops reached the soil surface of these plots because of the high litter cover, and only 1 plot which had total cover $>30 \%$ had a sediment yield greater than 0.1 tonnes $\mathrm{ha}^{-1}$, the assumed allowable soil loss (Fig. 3). This value was selected as $5 \%$ of the soil loss tolerance $(2$ 


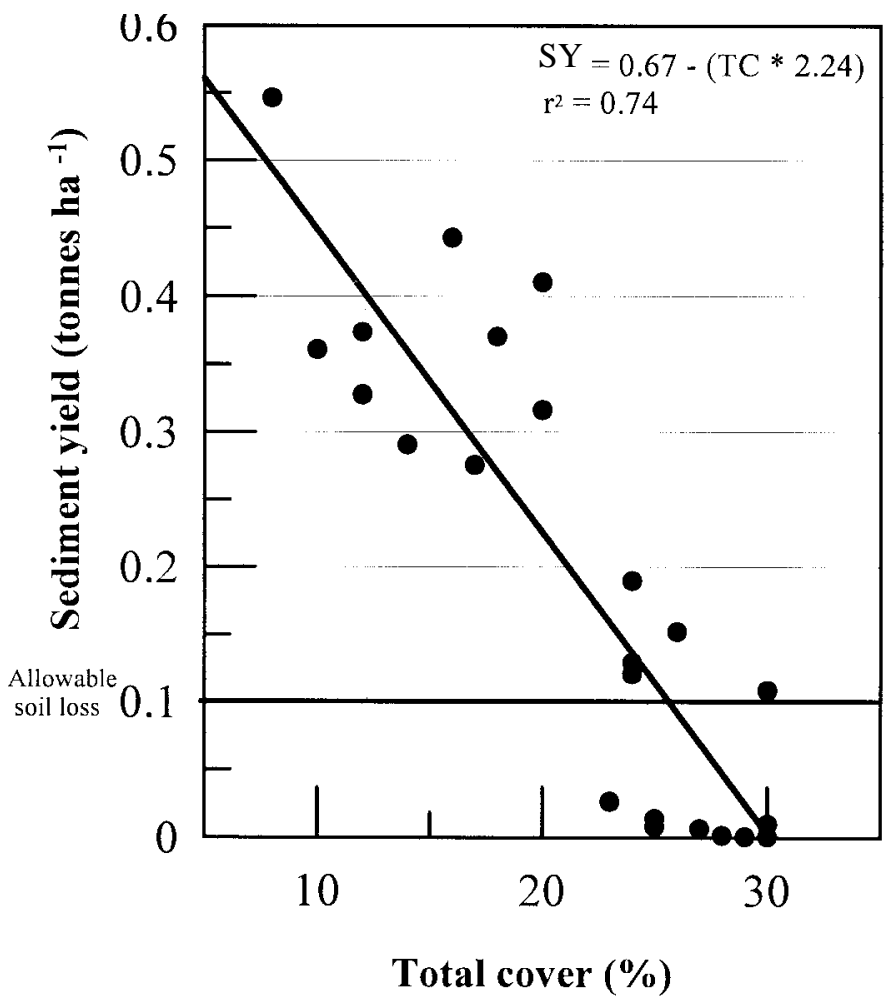

Fig. 2. Sediment yields (SY) for total cover (TC) less than or equal to $30 \%$. The regression line is statistically significant $(p<0.01$ ). Allowable soil loss was assumed to be $5 \%$ of the soil loss tolerance.

tonnes $\mathrm{ha}^{-1}$ ) for this soil (Morgan 1987). Sediment yields decreased for plots with total cover $>30 \%$, and were very low for total cover $>70 \%$, with the exception of 4 plots with total cover $=100 \%$. Runoff from these plots transported litter, which affected the sediment determination.

\section{Surface Roughness}

Surface roughness reflects the undulations of the soil surface and the surface cover, and is related to the effectiveness of the surface to influence sediment yield (Renard et al.1994). Regression analysis indicated that total cover accounted for only $19 \%$ of the variability in surface roughness, and surface roughness was weakly correlated to sediment yield $\left(\mathrm{r}^{2}=\right.$ 0.06). In this study, cover was the decision variable rather than surface roughness; thus surface roughness was less significant.

A possible explanation for the variability of sediment yield with surface roughness may be that plots with similar surface roughness had more or less developed micro-channel networks to transport sediment. Surface roughness did not reflect the degree of micro-channel development, and thus some plots with similar surface roughness produced much greater sediment yields than did others. An attempt to use point frame pin elevations to predict plot micro-topography and identify micro-channel networks was unsuccessful. Note that the pin spacing was approximately $5 \mathrm{~cm}$.

\section{Revised Universal Soil Loss Equation Analysis}

Using cover, soil, storm characteristics, and surface roughness, sediment yields were estimated using the Revised Universal Soil Loss Equation and a modified version of that equation (Benkobi et al. 1994). Results are shown in Figure 4, and compared with sediment yields determined from the simulations. Sixteen plots with sediment yields $>0.1$ tonnes $\mathrm{ha}^{-1}$ and plots with no measured sediment loss were not included in this figure. The Revised Universal Soil Loss Equation and modified version predicted very low sediment yields compared to simulation sediment yields although the modified version predicted slightly greater values than did the Revised Universal Soil Loss Equation. For total cover $>70 \%$, the comparison improved; however, sediment yields were generally very low. Neglecting the flushing of fines would reduce sediment yield values by approximately $60 \%$; however,

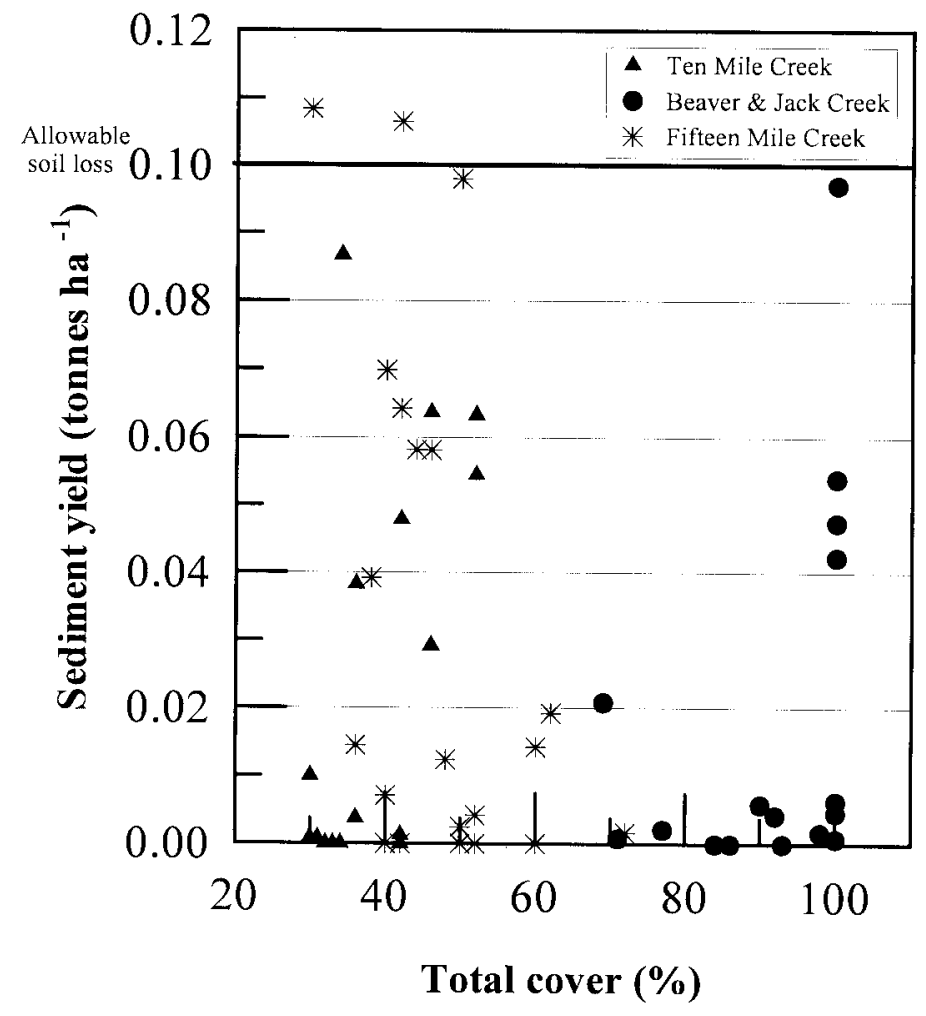

Fig. 3. Sediment yields for total cover greater than $30 \%$. The relationship is not statistically significant. Allowable soil loss was assumed to be $5 \%$ of the soil loss tolerance. 


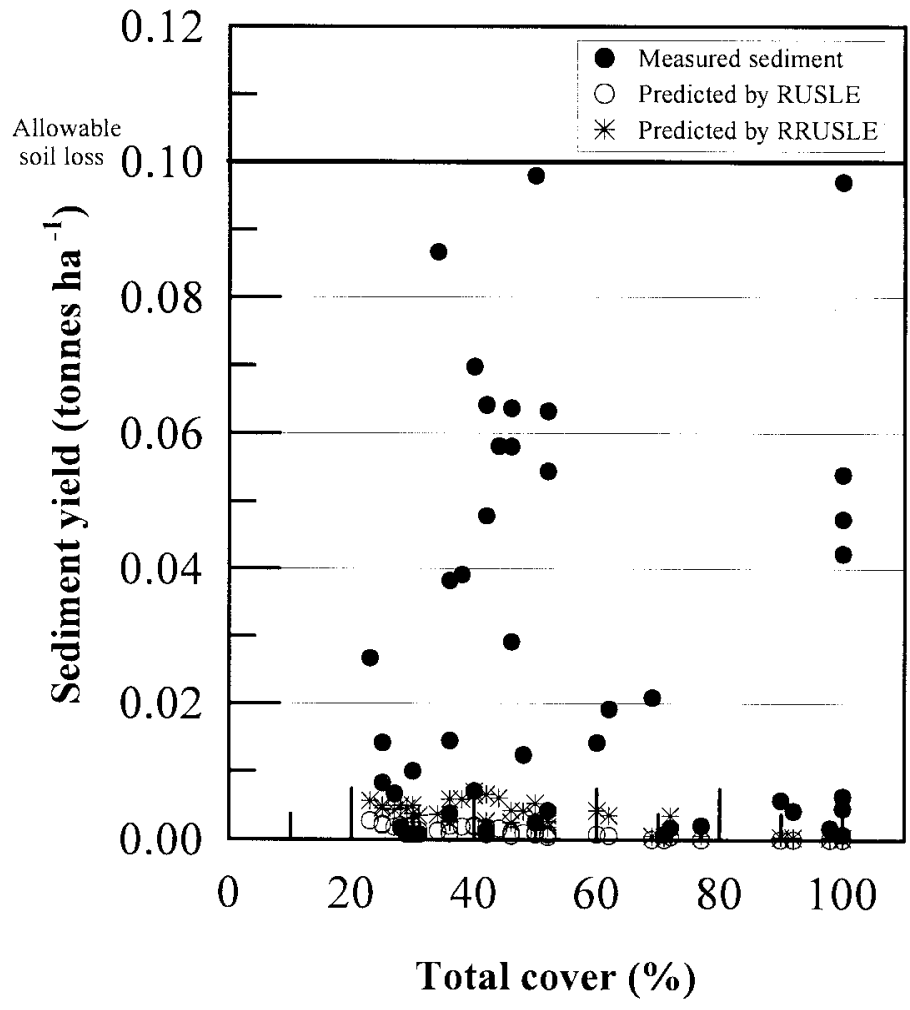

Fig. 4. Sediment yields predicted using the Revised Universal Soil Loss Equation (RUSLE) and a modified version of that equation (RRUSLE) (Benkobi et al. 1994), as a function of total cover for a most damaging storm. Sediment yields from the simulations are included for comparison; however, 16 simulations with sediment yields greater than 0.1 tonnes ha $^{-1}$ and 7 plots identified as outliers are not included. Allowable soil loss was assumed to be $5 \%$ of the soil loss tolerance.

measured values would still be considerably greater than predicted values.

Blackburn et al. (1992) concluded that erosion and runoff models were inadequate for rangelands because model parameters did not adequately account for rangeland variability. In this study, parameters were evaluated in detail yet the Revised Universal Soil Loss Equation and modified version of that equation predicted very low sediment yields compared to measured values. The degree of microchannel development on the plots and the resulting sediment transport capability may have been a factor in this comparison and in Blackburn's study. Micro-channel networks are not considered in current rangeland erosion and runoff models.

\section{Summary and Conclusions}

Rainfall simulations were used to evaluate soil erosion from 3 undisturbed upland Wyoming range sites. A 0.2 scale (2 plots, each $0.6 \times 2 \mathrm{~m}$ ) "Swanson type" simulator, was used to simulate a most damaging storm which was defined as the storm that produced the maximum average annual sediment load in 3 Wyoming streams. Sediment yields were evaluated in terms of cover and roughness on $9 \%$ slopes having highly erosive surface soils.

Sediment mass eroded from the plots was characterized by a high initial rate as loose sediment was flushed from the surface and a lower approximately steady level typical of longer duration-less intense storms. It is plausible that the source of most of the sediment flushed from the plots was accumulated eolian sediment deposition.

Assuming an allowable soil loss of 0.1 tonnes $\mathrm{ha}^{-1}$ (5\% of the allowable soil loss tolerance for the soil), $30 \%$ total cover provided adequate erosion protection for the most damaging storm. Sediment yields decreased moderately for greater than $30 \%$ total cover and were very low for greater than $70 \%$ total cover. The influence of cover on the relative development of micro-channel networks and thus on sediment transport off the plots, may explain these results.

Sediment yields from simulation plots were much higher than those predicted by the Revised Universal Soil Loss Equation or a modified version of that equation. However, the comparison improved for total cover values greater than $70 \%$. The silt and fine sand soil texture of the surface soil and the flushing of fines were partially responsible for differences between sediment yield values measured on simulation plots and predicted values. The relative degree of micro-channel development on the plots may also have contributed to these differences.

\section{References Cited}

Belsley, D.A. 1991. Conditioning diagnostics collinear and weak data in regression. John Wiley, New York, N.Y.

Benkobi, L., M.J. Trlica, and J.L. Smith. 1994. Evaluation of a refined surface cover subfactor for use in RUSLE. J. Range. Manage. 47:74-78.

Binkley, D. and T.C. Brown. 1993. Forest practices as non-point sources of pollution in North America. Water Res. Bull. 29:729-739.

Blackburn, W.H. and M.K. Wood. 1990. Influence of soil frost on infiltration of shrub coppice and dune interspace soils in southeastern Nevada. Great Basin Nat. 50:41-46.

Blackburn, W.H., F.B. Pierson, and M.S. Seyfried. 1990. Spatial and temporal influence of soil frost on infiltration and erosion of sagebrush rangelands. Water Res. Bull. 26:991-997.

Blackburn, W.H., F.B. Pierson, C.L. Hanson, T.L. Thurow, and A.L. Hanson. 1992. The spatial and temporal influence of vegetation on soil surface factors in semiarid rangelands. Trans. ASAE 35:479-486.

Bonham, C.D. 1989. Measurement of terrestrial vegetation. Wiley Interscience, New York, N.Y.

Branson, F.A., G.F. Gifford, K.G. Renard, and R.F. Hadley. 1981. Rangeland hydrology. Range Sci. Ser. No. 1. Kendall/Hunt Publ. Co. Dubuque, Iowa.

Cooper, C. 1979. 208 water quality management plan, Big Horn Basin, Wyoming, DEQ Regional Planing Office, Basin, Wyo.

de Ploey, J. and D. Gabriels. 1980. Measuring soil loss and experimental studies. In: M.J. Kirkby and R.P.C. Morgan (eds.) Soil erosion. John Wiley, New York, N.Y.

Devine, D.L., M.K. Wood, and G.B. Donart. 1998. Runoff and erosion from a mosaic tobosograss and burrograss community in northern Chihuahuan desert grassland. J. Arid Environ. 39:11-19.

Goldman, S.J., K. Jackson, and T.A. Burztynsky. 1986. Erosion and sediment control handbook. McGraw-Hill, New York, N.Y.

Haan, C.T., B.J. Barfield, and J.C. Hayes. 1994. Design hydrology and sedimentology for small catchments. Academic Press, San Diego, Calif. 
Heady, H.F. and R.D. Child. 1994. Rangeland ecology and management. Westview Press, Boulder, Colo.

Hogan, D.W. 1988. Wyoming statewide water quality assessment report. Wyoming DEQ Cheyenne, Wyo.

Huffsmith, R.L. 1988. Alternative sediment control in surface mine reclamation. MS Thesis, University of Wyoming, Laramie, Wyo.

Laflen, J.M., W.J. Elliot, J.R. Simanton, C.S. Holzhey, and K.D. Kohl. 1991. WEPP soil erodibility experiments for rangelands and cropland soil. J. Soil Water Cons. 46:39-44.

Lal, R. and W. Elliot. 1994. Erodibilty and erosivity. In: R. Lal (ed.) Soil erosion research methods. 2nd ed. St. Lucie Press, Delray Beach, Fla.

Linsley, R.K., M.A. Kohler, and J.L.H. Paulhus. 1982. Hydrology for engineers. 3rd ed. McGraw-Hill, New York, N.Y.

Morgan, R.P.C. 1987. Soil erosion and conservation. Longman Sci. Tech. Publ. Essex, England.

Naeth, M.A., A.W. Bailey, D.J. Luth, D.S. Chanasyk, and R.T. Hardin. 1991. Grazing impacts on litter and soil organic matter in mixed prairie fescue grassland ecosystems of Alberta. J. Range. Manage. 44:7-12.
Pearce, R.A., G.W. Frasier, M.J. Trlica, W.C. Leininger, J.D. Stednick, and J. L. Smith. 1998. Sediment filtration in a montane riparian zone under simulated rainfall. J. Range Manage. 51:309-314.

Pease, P.P., V.P. Tchakerian, and N.W. Tindale. 1998. Aerosols over the Arabian Sea: geochemistry and source areas for aeolian desert dust. J. Arid Environ. 39:477-496.

Ponce, V.M. 1989. Engineering hydrology principles and practices. Prentice-Hall, Englewood Cliffs, N.J.

Renard, K.G., J.M. Laflen, G.R. Foster, and D.K. McCool. 1994. The revised universal soil loss equation. In: R. Lal (ed.) Soil erosion research methods. 2nd ed. St. Lucie Press, Delray Beach, Fla.

Schreiber, H.A. and K.G. Renard. 1978. Runoff water quality from varying land uses in southeastern Arizona. J. Range Manage. 31:274-279.

Seyfried, M.S. 1991. Infiltration patterns from simulated rainfall on a semiarid rangeland soil. J. Soil Sci. Soc. Amer. 55:1726-734.

Simanton, J.R., M.A. Weltz, and H.D. Larson. 1991. Rangeland experiments to parameterize the water erosion prediction project model: vegetation canopy cover effects. J. Range Manage. 44:276-282.
Skidmore, E.L. 1994. Wind erosion. In: R. Lal (ed.) Soil erosion research methods. 2nd ed. St. Lucie Press, Delray Beach, Fla.

Weltz, M.A. and W.H. Blackburn. 1995. Water budget for south Texas rangelands. J. Range Manage. 48:45-52.

Weltz, M.A. and M.K. Wood. 1986. Short duration grazing in central New Mexico: effects on sediment production. J. Soil Water Cons. 41:262-266.

Weltz, M.A., A.B. Arslan, and L.J. Lane. 1992. Hydraulic roughness coefficients for native rangelands. J. Irrig. Drain. Eng. 118:776-790.

Wilcox, B.P. and M.K. Wood. 1988. Hydrologic impacts of sheep grazing on steep slopes in semiarid rangelands. J. Range. Manage. 41:303-306. 